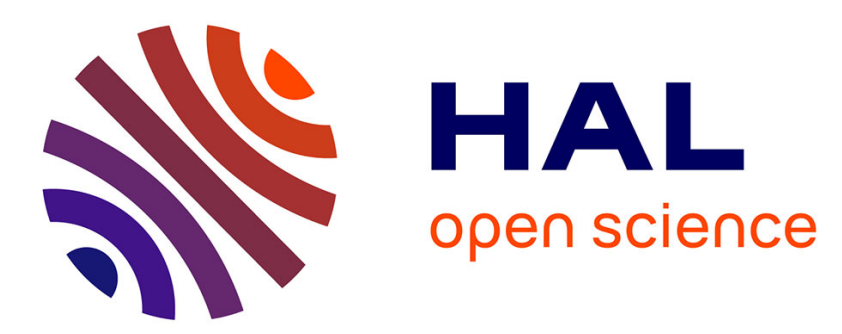

\title{
Assessment of the PCDD/F fate from MSWI residue used in road construction in France
}

Rabia Badreddine, Denis Francois

\section{To cite this version:}

Rabia Badreddine, Denis Francois. Assessment of the PCDD/F fate from MSWI residue used in road construction in France. Chemosphere, 2009, 74 (3), pp 363-369. 10.1016/j.chemosphere.2008.09.028 . hal-00425414

\section{HAL Id: hal-00425414 https://hal.science/hal-00425414}

Submitted on 12 Feb 2014

HAL is a multi-disciplinary open access archive for the deposit and dissemination of scientific research documents, whether they are published or not. The documents may come from teaching and research institutions in France or abroad, or from public or private research centers.
L'archive ouverte pluridisciplinaire HAL, est destinée au dépôt et à la diffusion de documents scientifiques de niveau recherche, publiés ou non, émanant des établissements d'enseignement et de recherche français ou étrangers, des laboratoires publics ou privés. 
IINERIS, DRC/DESP, Parc Technologique Alata BP 2, 60550 Verneuil-en-Halatte, France 'Laboratoire Central des Ponts-et-Chaussées, centre de Nantes, Route de Bouaye, BP 4129, 44341 Bouguenais cedex, France

\section{Corresponding author:}

Rabia BADREDDINE

DESP/DRC INERIS

Parc Technologique Alata

B.P. 2

60550 Verneuil-en-Halatte

FRANCE

Fax : 0344556556

E-mail. rabia.badreddine@ineris.fr 


\section{Abstract}

31 MSWI fly ash is susceptible to contain high amount of dioxins (PCDD) and furans 32 (PCDF). However, the use of MSWI residues for road construction started in France at period when the mixture of MSWI Bottom Ash with MSWI fly ash was used. From four old road sites, MSWI residues, road soils, reference soils and geo-textiles were sampled and their PCDD/F contents were analyzed. MSWI residues show a great

36

Keywords: incineration, ash, road, dioxin, furan, particle heterogeneity but also high amounts of PCDD/F between 14 and $2960 \mathrm{ng}$ I-TEQ. $\mathrm{kg}^{-1}$ DM. Road soils show less heterogeneity and contents between 0.57 et $7.23 \mathrm{ng}$ ITEQ.kg ${ }^{-1}$ DM lower than ordinary soils. Moreover, the specific analysis of the 17 toxic PCDD/F congeners (notably the 2,3,7,8-TetraCDD) indicates the very low noxiousness of road soils. The study also allows to assert the relation between the MSWI residue particle size and the PCDD/F content.

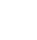

.

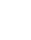

.

(1)


54 In many areas across the world where the high demand of construction materials compared to the availability of natural materials, as well as the lack of available space for waste disposal, are a problem, the use of by-products and wastes for road construction has been seen for a long time as an appropriate solution to reduce the amount of disposed materials and to provide at the same time alternative materials for construction. A typical case of these alternative materials is that of the Municipal Solid Waste Incinerator (MSWI) residue which is produced from the household wastes combustion and used for road and car-park construction. In France, the use of MSWI residue in road construction is supervised since the 90's through an order (1991) and a memorandum (1994) both from the ministry of Environment. The environmental assessment of MSWI bottom ash is based on the measurement of its unburned fraction and the leaching potential of some heavy metals, arsenic, sulfate and total organic carbon. Yet, MSWI residues may contain persistent organic pollutants (POP) such as polychlorinated dibenzo-dioxins (PCDD) and polychlorinated dibenzo-furans (PCDF). PCDD/F molecules are poorly water soluble and leaching tests are known for not being relevant toward them, nonetheless, the affinity of PCDD/F molecules for particles is also known, and such affinity may be higher toward the finest particles. As a consequence, one wonders if under the effect of rainwater infiltration into the road body, the washing of the MSWI residue layer may induce the transfer, downward, of PCDD/F molecules bound to the

74 finest particles of the material. In such a case, on road sites, compared to some 75 reference soils, an increase of the PCDD/F content in the soil underlying the road 76 (called the road soil), may be observed. 
77 In order to answer to this question, PCDD/F contents of MSWI residues sampled into 78 old road structures, were analyzed (including an assessment of their noxiousness).

79 The relation between the dimension of MSWI residue particles and the PCDD/F content was studied. Then MSWI residue PCDD/F contents were compared to those measured in the road soil and in neighbouring soils (local references).

As before the enforcement of the 1991 order - thus PCDD/F compounds - MSWI residues were susceptible to contain higher amounts of fly ash, the present study was focused on pre-1991 constructions. At the same time, this allows to assess the medium-term state of road soils.

\section{Context of the study}

\subsection{Production of PCDD/F during household waste incineration}

As a result of incomplete combustion, incineration of household waste produces several organic compounds such as chlorinated species (polychlorinated biphenyls (PCB), polychlorinated dibenzodioxins (PCDDs), and polychlorinated dibenzofurans (PCDFs)). Two temperature ranges are responsible for the production of persistent organic pollutant (POP). The first one $\left(200\right.$ to $\left.400^{\circ} \mathrm{C}\right)$ which results from a catalysed reaction taking places on the ash particles present in combustion systems. The second one $\left(500\right.$ to $\left.800^{\circ} \mathrm{C}\right)$ is the result of a rearrangement of chlorinated precursors such as chlorophenols and chlorobenzenes in the gas phase (Stanmore, 2004).

Dioxin air emissions from incinerators have decreased in the last decade due to improvements in the pollution control technology and to the regulation implementation and enforcement. Two orders of 20 September, one for hazardous waste and another one for non hazardous waste, both limit the level of PCDD/F emission to $0.1 \mathrm{ng} \cdot \mathrm{m}^{-3}$. 


\subsection{Use of MSWI residues for road construction in France}

102 The use of MSWI residue started in France during the 1950's in the area of Paris and spread all over the country during the 1980' - 1990's, a period during which many incinerators were built (AGHTM, 1994).

As for some other alternative materials (coal fly ash, blast furnace slag...), the use of MSWI residue was codified by the ministry for public works and transports, allowing

107 its assimilation to one of the various kinds of natural materials considered for the classical road structure design (MELT, 1997; SETRA and LCPC, 2000). The analogy is based on geo-technical responses of the MSWI residue sample to a set of usual standard mechanical tests (resistance to fragmentation and wear, sand equivalent,

111 surface cleanliness, compactibility...).

112 Until the 1990's the environmental question about the use of MSWI residue was not

113 seen as a major concern. In 1991, an order required from the $1^{\text {st }}$ of December 1992 , 114 the separating of MSWI residue into bottom ash (the fraction of the incineration residue which is collected from the incinerator grate) and fly ash (the fraction made of

116 fine particles carried away by the flux of combustion gas which is later captured by

117 dust collectors). While the production of MSWI bottom ash is around $250 \mathrm{~kg}$ per ton

118 of incinerated residue, the production of fly ash is $20 \mathrm{~kg}$ per ton (AGHTM, 1994;

119 Autret et al., 2007). Due to its high pollutant potential (notably high content in

120 chlorides, arsenic, lead, zinc, mercury, cadmium and organic compounds), MSWI fly

121 ash was classified as hazardous waste and has to be directed toward specific

122 landfills for hazardous waste. Usually, the MSWI bottom ash fraction is classified as

123 non-hazardous waste and is authorized in non-hazardous waste landfill, or also

124 potentially authorized for road construction under specific conditions. Indeed, in 125 1994, a memorandum from the Ministry in charge of the Environment (French 
126 Environment Ministry, 1994) provided recommendations for the use of MSWI bottom

127 ash in road construction (embankment, capping layers, subgrades....). The use of

128 MSWI bottom ash depends on its unburned fraction and on its leaching potential

129 controlled through a standard batch leaching test (NF X 31-210, 1992). The 1994

130 memorandum sets maximum limit values related to the leachate: its global soluble

131 fraction (total dissolved solids), plus specific limit values for seven chemical

132 parameters: arsenic, cadmium, chromium VI, lead, mercury, sulfate and total organic

133 carbon.

$134 \quad 2.3$ Knowledge about the PCDD/F fate in the road environment

135 The 1994 memorandum did not set any particular recommendation regarding dioxins 136 and furans. Since the 1990's, MSWI residue (and more specifically MSWI bottom 137 ash) has been extensively studied in France and worldwide from the environmental 138 point of view. This was essentially carried out with relation to its heavy metal leaching 139 potential and poorly with relation to its organic pollutants, notably regarding PCDD/F 140 content and release risk (Chandler et al., 1997, Bartet et al., 2001). Consequently, as 141 opposite to heavy metals for which laboratory, lysimeter and some field studies have

142 provided leaching data (Silvestre and Rampignon, 1995; Adam et al., 1996;

143 Drouadaine et al., 1997; Paris et al., 1997; Drouadaine and Badreddine, 2003), very 144 little knowledge exists today regarding the fate of PCDD/F, notably possible transfer 145 of $\mathrm{PCDD} / \mathrm{F}$ to the open environment from the use of MSWI residues in road 146 infrastructures.

147 In the French context, this issue is essentially related to the effect of pre-1991 MSWI 148 residues, as at that time bottom and fly ashes were not separated. Considering on 149 the one hand the long term potential effect of PCDD/F, and on the other hand the 150 infiltration of rainfall through road surface (van Ganse, 1978) and the permeability of 
151 the MSWI residue layers (i.e. $10^{-5}$ to $10^{-4} \mathrm{~m} . \mathrm{s}^{-1}$ ) (François et al., 2003), understanding

152 the fate of PCDD/F hold into old MSWI residues used in road structures has became

153 a necessity. Indeed, due to its relatively poor mechanical properties, MSWI residue

154 has primarily been used by road engineers mainly in the deeper layers of the road

155 structure (SETRA and LCPC, 2000), where mechanical constraints are the lowest,

156 immediately above the underlying natural soil. The latter (called road soil), due to its

157 direct contact with the MSWI layer and to its ability to retain pollutants represents a

158 major target to be considered in the context of alternative material use in road

159 construction (Jullien and François, 2006).

1603 Materials

\section{$161 \quad 3.1$ Road site identification}

162 In order to take advantage of the longest possible period of contact between the

163 MSWI residue layer and the road soil, road sites for study were chosen as old as

164 possible. However, due to of the lack of written records for the oldest roads, it was

165 only possible to go back in time as early as 20 years ago, thanks to the memory of

166 the people who took part to the construction. For more recent sites (around 10 years

167 old), more data was available.

168 The road body is a multi-layer structure. The pavement layers (surface course, base

169 course, sub-base) are built on the pavement foundation, consisting of the natural

170 ground after earthworks (scrapped and compacted) called the subgrade, generally

171 topped with a capping layer in the French design technique (SETRA and LCPC,

172 2000). Figure 1a presents the different road layers of a complete structure. In

173 practice, depending on the physical stress expected on the road body during its use 
174 (load due to traffic, climatic agents) and on the properties of the road materials, the

175 number of layers in the structure and their thickness can vary.

176 When the natural soil on which the road structure is built contains too many fine 177 particles, this may induce a transfer of fine particles from the road soil to the upper 178 layer. This phenomenon can induce an increase of the upper layer sensitivity to 179 moisture variation, detrimental to its bearing capacity. This risk is usually avoided 180 using a geo-textile; such a geo-textile was found in two of the investigated sites.

181 Four sites (noted A, B, C and D) were investigated from various regions in France.

182 Sites A and B were built in the second half of the 1970's, while sites C and D were 183 built between 1991 and 1994. Their structure is described in Figure 1b. In both site, 184 MSWI residues were used as 0-31.5 $\mathrm{mm}$ unbound graded aggregates.

185 Site $\mathrm{A}$ is the private road of a MSW incinerator plant, which essentially bears a heavy 186 lorry traffic. The structure corresponds to a flexible pavement in which the MSWI 187 residue was used in a thick sub-base layer $(70 \mathrm{~cm})$. The road soil is sandy. Built in 188 1978, site A was sampled at the age of 20.

189 Site B is an urban pavement which only undergoes light vehicle traffic. The structure 190 is that of a flexible pavement in which the MSWI residue was used in the sub-base 191 layer $(25 \mathrm{~cm})$. The underlying soil is silty. Built in 1976, Site B was sampled at the 192 age of 22.

193 Site $\mathrm{C}$ is another urban pavement which undergoes light traffic. The structure 194 corresponds to a semi-rigid pavement in which the MSWI residue was used in a quite 195 thick sub-base layer $(40 \mathrm{~cm})$, topped with a bound layer made of blast furnace slag 196 and coal fly ash. Due to the silt nature of the road soil, a geo-textile was laid by the 
197 road constructor below the MSWI residue layer in order to prevent fine particles lifting

198 towards the sub-base layer. Built in 1992, site C was sampled at the age of 9 .

199 Site $\mathrm{D}$ is a public car park platform. The uncovered structure (a simple $1 \mathrm{~cm}$-thick

200 gravelling) is unusual for traditional car parks but is sometime chosen for 201 occasionally used ones. The MSWI ash is used in the base layer $(30 \mathrm{~cm})$. Due to the 202 silty nature of the road soil, a geo-textile was also laid by the road constructor below 203 the MSWI residue layer in order to prevent fine particles lifting towards the base 204 layer. Built in 1994, site D was sampled at the age of 9.

\subsection{Material sampling}

\subsubsection{Sampling}

207 On each site, the sampling operation starts by digging a trench in the pavement, 208 down to the top of the MSWI residue layer. For safety reasons, on circulated roads, 209 the trench is dug on the road edge side. No such consideration had to be taken into 210 account regarding the car park. In all case, beforehand, information is collected 211 regarding the location of buried networks (water, gas, electricity...).

212 Usually, the thickness of the MSWI residue layer is not known exactly; on one site it 213 can vary by few centimeters from one point to another, which makes preferable, 214 when possible, to dig more than one trench. A core sampler is used to collect at once 215 the MSWI residue layer and the road soil. Then, the real thickness of the MSWI 216 residue layer at the sampling point is measured on the core sample. The thickness of

217 the sampled underlying soil is also measured. The core sample can then be cut in 218 different sub-layers in order to assess the contaminant content at different depths.

219 The upper sub-sample of the road soil, just below the MSWI residue layer, is always 220 rather thin (usually $5 \mathrm{~cm}$ thick). Samples for analysis are collected in the middle of 
221 the core section. This is a precaution avoiding peripheral contamination from the 222 upper levels to the lower ones, as while the core sampler is pushed in, particles can 223 move along its internal wall.

224 When the road site makes it easy to obtain a reference situation of the soil away from 225 the MSWI residue road layer influence, reference samples are collected with the core 226 sampler for analysis and comparison with the road soil. Providing data on the 227 surrounding situation regarding PCDD/F influence on the site, the so-call reference 228 soil makes it possible to have a view of the net impact on the road soil. For all 229 materials, before analysis, all samples were stored in plastic bags and drums, 230 hermetically closed.

\section{$231 \quad$ 3.2.2 Samples}

232 Table 1 provides an overview of the set of samples that were analyzed, together with 233 their codification, the numbering is for the trench (1,2 or 3$)$. Soil samples were 234 collected at different depths in order to detect any vertical content variation. Depth of sampling was conditioned by the soil own-thickness.

236 For sites A, B and C it was possible to identify a reference soil, but not for site D. In 237 site $A$, four $A_{R}$ samples were collected for PCDD/F content analysis $(0-20 \mathrm{~cm}, 20-40$ $238 \mathrm{~cm}, 40-60 \mathrm{~cm}$ and 80-95 cm). In sites B, two samples were collected: 0-20 cm and $23960-80$ for $B_{R}$. In site $C$, the reference soil $\left(C_{R}\right)$ was not sampled as deep as the two 240 others: $0-5 \mathrm{~cm}$ and $5-15 \mathrm{~cm}$.

241 Regarding MSWI residues, in site A, two trenches were dug into the road structure.

242 Only one sample was collected in the first trench $\left(A_{M 1}\right)$ because at that point the 243 MSWI residue layer was thin $(12 \mathrm{~cm})$. In the second trench $\left(A_{M 2}\right)$, the layer thickness 244 was greater $(65 \mathrm{~cm})$ and four samples were collected in the MSWI residue $\left(A_{M 2 / 14-29}\right.$; 
$245 A_{M 2 / 35-45} ; A_{M 2 / 45-65}$ and $\left.A_{M 2 / 65-85}\right)$. In site $B$, one trench was dug, providing one sample $246\left(B_{M 1}\right)$ of MSWI residue $(35-60 \mathrm{~cm})$. Similarly for site $C\left(C_{M 1}\right)$, only one sample was 247 collected $(50-88 \mathrm{~cm})$. Lastly, in site $\mathrm{D}$ three trenches were dug providing each one a 248 sample $\left(D_{M 1}, D_{M 2}\right.$ and $\left.D_{M 3}\right)$ with the same geometrical characteristics $(10-30 \mathrm{~cm})$.

249 Regarding road soils, in site A, three samples were collected in the sandy road soil of 250 trench $\mathrm{T} 1\left(\mathrm{~A}_{\mathrm{S} 1}\right)(32-37 \mathrm{~cm}, 37-42 \mathrm{~cm}$ and $42-52 \mathrm{~cm})$. Three road soil samples were 251 also collected at trench T2 $\left(\mathrm{A}_{\mathrm{S} 2}\right)(29-35 \mathrm{~cm}, 85-90 \mathrm{~cm}$ and $95-105 \mathrm{~cm})$. Sample $A_{\mathrm{S} 2 / 29-}$ 252 35 taken from trench T2 is a thin sand layer which accidentally slid on the MSWI residue during the road work; it was not removed and has remained inserted in the MSWI residue layer since then. In site $B\left(B_{S 1}\right)$, two samples were collected in the silty road soil $\left(B_{S 1 / 60-70}\right.$ and $\left.B_{S 1 / 70-80}\right)$. In site $C$, a single road soil sample (silty) was collected $\left(\mathrm{C}_{\mathrm{S} 1 / 88-93}\right)$. In site $\mathrm{D}$, three silty road soil samples were collected in trench $\mathrm{T} 1$ $\left(D_{S 1 / 30-35} ; D_{S 1 / 35-45}\right.$ and $\left.D_{S 1 / 93-103}\right)$; two in trench $T 2\left(D_{S 2 / 30-35}\right.$ and $\left.D_{S 2 / 35-45}\right)$; and a single sample in trench $\mathrm{T3}\left(\mathrm{D}_{\mathrm{S} 3 / 30-35}\right)$.

In sites $C$ and $D$, during construction geo-textiles were laid between the MSWI 260 residue layer and the road soil. One sample of geo-textile was collected in the trench 261 of site $C\left(C_{G 1}\right)$ and two geo-textile samples were collected at site $D$, one from trench $262 \mathrm{~T} 1\left(\mathrm{D}_{\mathrm{G} 1}\right)$, the second from trench $\mathrm{T} 2\left(\mathrm{D}_{\mathrm{G} 2}\right)$.

\section{Methods}

\section{$264 \quad 4.1$ Grading of materials}

265 The total sample, dried at $105^{\circ} \mathrm{C}$, is sieved at $2 \mathrm{~mm}$. The fraction below $2 \mathrm{~mm}$ is 266 sieved in a dried phase in a stainless steel sieve to separate the fractions below 1 $267 \mathrm{~mm}$ and $0.5 \mathrm{~mm}$. The particle size distribution of the fraction below $0.5 \mathrm{~mm}$ is 268 achieved using the laser diffraction technique (Mastersizer, Malvern Instrument). 


\subsection{PCDD/F analysis}

270 Determination of dry matter content was achieved by drying subsamples at $105^{\circ} \mathrm{C}$ 271 following the standard EN ISO 11465.

272 The samples were beforehand dried at room temperature. The dried samples were 273 treated and digested with chlorydric acid. Materials (MSWI residues and soil 274 samples) were prepared using an accredited method, based on the standard 275 EN 1948-2 and EN 1948-3, which consists in extracting the analyzed components 276 with mixture of toluene and acetone. This step is followed with several stages of 277 clean-up by chromatography on columns filled with absorbents using solvents or 278 various elution strength. After filtration, the dioxin measurement requires a solid/liquid 279 extraction followed with a cleaning up step. The purified extracts are reduced to a 280 minimum volume and then mixed in a solvent compatible with the final analysis by 281 gas chromatography.

282 The total eluate was prepared following the same methodology as the one used for 283 MSWI residues.

284 Analyses of PCDD/F were carried out by means of a High Resolution Mass 285 Spectrometry coupled with a High Resolution Gas Chromatography (HRMS/HRGC) 286 VG/AutoSpec.

287 The analysis consisted in measuring 17 toxic congeners (7 congeners for PCDD and 28810 congeners for PCDF). The seven dioxin congeners are 2,3,7,8-TetraCDD; 289 1,2,3,7,8-PentaCDD; 1,2,3,4,7,8-HexaCDD; 1,2,3,6,7,8-HexaCDD; 1,2,3,7,8,9290 HexaCDD; 1,2,3,4,6,7,8-HeptaCDD and OctaCDD. The ten furan congeners are 291 2,3,7,8-TetraCDF; 1,2,3,7,8-/1,2,3,4,8-PentaCDF; 2,3,4,7,8-PentaCDF, 1,2,3,4,7,8292 /1,2,3,4,7,9-HexaCDF; 1,2,3,6,7,8-HexaCDF; 1,2,3,7,8,9-HexaCDF; 1,2,3,4,6,7,8- 
HeptaCDF; 1,2,3,4,7,8,9-HeptaCDF and OctaCDF. Interferences with the other 193

294 non toxic congeners and some other components such as Polychlorobiphenyls 295 (PCBs), Polychloroterphenyls (PCTs), or Polychloronaphtalens (PCNs) are 296 eliminated. The determination of congeners was realized by the isotopic dilution 297 method using isotope as interne markers for congeners identification and 298 quantification.

299 The concentration of one PCDD or PCDF congener can be converted into an 300 International Toxic Equivalent Quantity (I-TEQ), with a Detection Limit (DL) of 1.22 301 nanogram I-TEQ. $\mathrm{kg}^{-1}$ of dry material (noted DM) and an accuracy of $4.7 \%$ on the 302 Toxic Equivalent value. The model used for determining the I-TEQ is NATO (1998).

\section{$303 \quad 4.3$ Leaching}

304 Regarding the geo-textiles found on two sites, before chemical analyses, the 305 recovery of particles was realized by means of leaching, intended to wash the geo306 textile. The operation was renewed until the complete extraction.

307 Regarding MSWI residues, as PCDD/F are not water soluble compounds (Sakai et 308 al., 2000a), the purpose of the test was not to assess their solubility but their possible 309 residual release associated to very fine particle extraction (namely below $0.45 \mu \mathrm{m}$ in 310 the condition of the test due to the filter size) under the effect of water flushing. The 311 leaching test was performed for MSWI residues from sites B and D following the EN 312 12457-2 standard protocol (2002). Determination of the dry matter content was made 313 after drying of test portion at $105^{\circ} \mathrm{C}$, according to the international standard ISO 31411465 (1994). The liquid/solid separation is performed by means of filtration on a $3150.45 \mu \mathrm{m}$ membrane filter using a pressure filtration device. The eluate obtained after 316 filtration was analyzed to determine PCDD/F compounds' nature and quantity. 


\section{Results}

319 Results concerning old MSWI residues are first presented. Then are those of geo-

320 textiles, road soils and reference soils. All material samples are defined in relation to

321 their depth from the surface (expressed in centimeters) and all PCDD/F contents are

322 expressed in nanogram of I-TEQ per kilogram of dry matter (noted ng I-TEQ.kg ${ }^{-1}$

323 DM).

324 The PCDD/F congener with the greatest toxic potential, and for which the greatest

325 amount of toxicological data is available, is 2,3,7,8-TetraCDD (Mac Kay, 2002). Its

326 content in all material samples is provided (in ng. $\mathrm{kg}^{-1} \mathrm{DM}$ ).

327 Additionally, in order to assess the distribution of the different PCDD/F compounds in

328 the different materials the sum of the seven PCDD congeners and that of the ten

329 PCDF congeners was calculated (in ng. $\mathrm{kg}^{-1} \mathrm{DM}$ ).

$330 \quad 5.1$ MSWI residues' characteristics

\subsubsection{PCDD/F contents in MSWI residues}

332 Results are presented in Table 2. In site A, the only one showing values below 100 333 ng I-TEQ.kg ${ }^{-1}$ DM, the PCDD/F content for the MSWI residue in trench T1 $\left(A_{M 1}\right)$ is

$33414.0 \mathrm{ng}$ I-TEQ. $\mathrm{kg}^{-1}$ DM. In trench T2 $\left(\mathrm{A}_{\mathrm{M} 2}\right)$, it increases from the upper sample to the

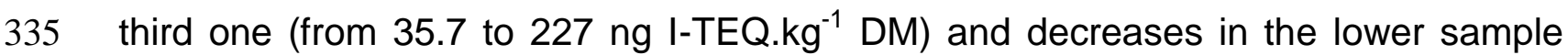
336 (63.2 ng I-TEQ.kg $\left.{ }^{-1} \mathrm{DM}\right)$.

337 In site $\mathrm{B}\left(\mathrm{B}_{\mathrm{M} 1}\right)$, the $\mathrm{PCDD} / \mathrm{F}$ content for the MSWI residue is $721 \mathrm{ng}$ I-TEQ. $\mathrm{kg}^{-1} \mathrm{DM}$, 338 three time higher than the maximum value measured in site $\mathrm{A}$. 
339 In site $\mathrm{C}\left(\mathrm{C}_{\mathrm{M} 1}\right)$, the $\mathrm{PCDD} / \mathrm{F}$ content is similar to the maximum value found in site $\mathrm{A}$

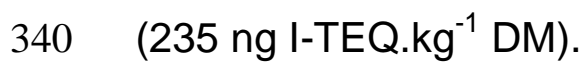

341 The three trenches of site $D\left(D_{M 1}, D_{M 2}\right.$ and $\left.D_{M 3}\right)$ show, by far, the highest PCDD/F

342 contents. These contents are respectively 1960, 2160 and $1640 \mathrm{ng} \mathrm{I-TEQ.kg}^{-1}$ DM.

\subsubsection{Relation between PCDD/F amount and particle size}

344 A sample with a high PCDD/F content $\left(D_{M 1}\right)$, was chosen in order to assess the 345 possible relation between the particle size distribution of MSWI residues and their $346 \mathrm{PCDD} / \mathrm{F}$ load. PCDD/F contents related to fractions $<0.1 \mathrm{~mm} ; 0.1-0.5 \mathrm{~mm} ; 0.5-1$ $347 \mathrm{~mm} ; 1-2 \mathrm{~mm} ; 2-10 \mathrm{~mm} ; 10-31.5 \mathrm{~mm}$ of the material are presented in Figure 2.

348 The PCDD/F contents of fractions between 2 and $31.5 \mathrm{~mm}$ are similar, comprised

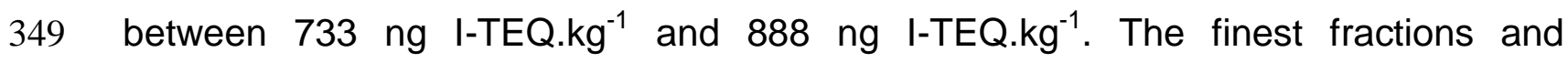

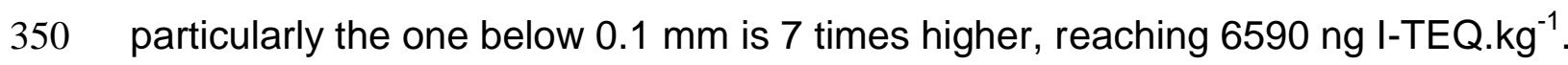

\section{$351 \quad$ 5.1.3 Leaching of MSWI residues}

352 The leaching test was carried out in order to detect the proportion of PCDD/F 353 particles inferior to $0.45 \mu \mathrm{m}$. For both sites ( $B$ and $D$ ), leaching results (Table 3 ) show

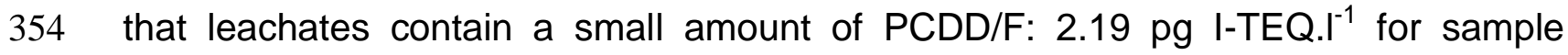
$355 \mathrm{~B}_{\mathrm{M} 1 / 35-60}$; and 4.4.1 pg I-TEQ. ${ }^{-1}$ for sample $\mathrm{D}_{\mathrm{M} 1 / 10-30}$. Brought to the mass of dry 356 material involved in the leaching test, such releases are respectively equal to 0.019 357 ng I-TEQ. $\mathrm{kg}^{-1} \mathrm{DM}$ for the first sample, and $0.041 \mathrm{ng} \mathrm{I-TEQ.} \mathrm{kg}^{-1} \mathrm{DM}$ for the second.

\section{$358 \quad 5.2$ Geo-textiles' load of PCDD/F}

359 The load of PCDD/F on the geo-textile from site $C\left(C_{G 1}\right)$ is $175 \mathrm{ng} \mathrm{I-TEQ.kg-1} \mathrm{DM}$ 360 (Table 4). Site D geo-textile samples show far higher values : 754 ng I-TEQ.kg ${ }^{-1}$ DM 361 in trench $T 1\left(D_{G 1}\right)$, and $1600 \mathrm{ng}$ I-TEQ. $\mathrm{kg}^{-1} \mathrm{DM}$ in trench T2 $\left(\mathrm{D}_{\mathrm{G} 2}\right)$. The latter value is 362 close to the content of the MSWI residue layer above. 


\subsection{PCDD/F contents in road soils}

364 For site $B\left(B_{S_{1}}\right)$, it varies from 7.23 to 0.57 ng I-TEQ. $\mathrm{kg}^{-1} \mathrm{DM}$ from the upper to the 365 lower sample. In site $\mathrm{C}\left(\mathrm{C}_{\mathrm{S1/88-93}}\right)$, the single sample value is $2.87 \mathrm{ng}$ I-TEQ. $\mathrm{kg}^{-1} \mathrm{DM}$. 366 In site $D$, from the top to the bottom of the investigated thickness in trench $T 1\left(D_{S 1}\right)$,

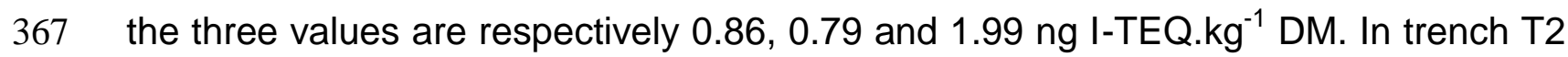
$368\left(D_{\mathrm{S} 2}\right)$, the values are of the same order (2.22 and $0.64 \mathrm{ng}$ I-TEQ. $\left.\mathrm{kg}^{-1} \mathrm{DM}\right)$. Lastly, 369 trench T3 sample (D ( $\left.D_{S 3}\right)$ PCDD/F content is 2.04 ng I-TEQ.kg-1 DM (Table 5).

370 Site A presents a contrasted situation regarding its two trenches. In trench T2 $\left(A_{S 2}\right)$, 371 the PCDD/F contents of the three samples are in the range of the previous cases $\mathrm{B}$,

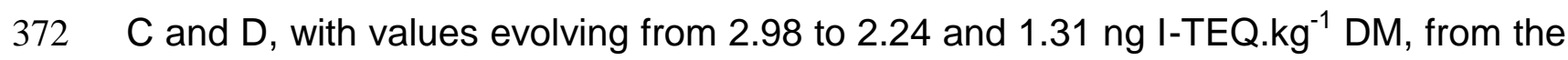
373 upper to the lower sample. On the other hand, in trench T1 $\left(A_{S 1}\right)$, whereas the two

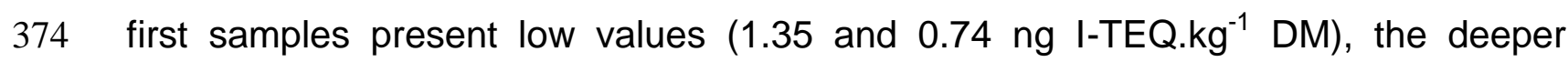

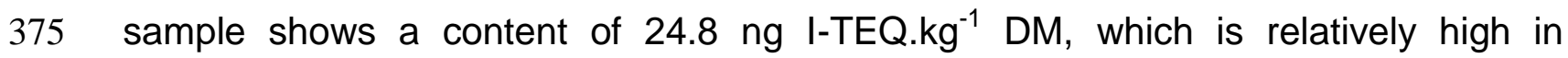
comparison with the content of the MSWI residue layer located just above (i.e. 14.0 ng I-TEQ. $\left.\mathrm{kg}^{-1} \mathrm{DM}\right)$. As a consequence, this values $\left(A_{S 1 / 42-52}\right)$ is very uncertain and will not be considered in the interpretation.

\subsection{PCDD/F contents in reference soils}

380 Results are presented in the Table 6. In site $A\left(A_{R}\right)$, the PCDD/F content of the

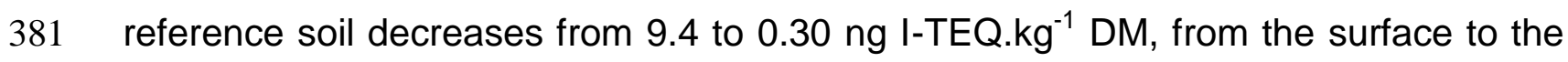
382 deeper sample. The top sample value can be related to the atmospheric 383 contamination in the vicinity of the incineration plant, from the chimney, at a time (the 384 1970's) when fume de-pollution by means of old dust separators was not as efficient 385 as the nowadays air pollution control systems (Chandler et al., 1997) 
386 In site $B\left(B_{R}\right)$, contents are homogeneous and low (1.05 and 0.79 ng I-TEQ.kg ${ }^{-1}$ DM).

387 Contrary to site A, it seems that no particular source of pollution has an effect on the 388 vertical profile of content.

389 Site $C\left(C_{R}\right)$ shows intermediate values between the two previous ones i.e. 5.40 and

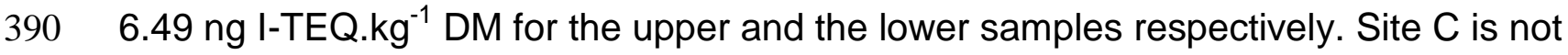

391 located in the vicinity of a particular source of PCDD/F, but it is however located in a 392 large urban area with several potential sources.

\section{5.5. Distribution of PCDD/F congeners in the road structure}

394 Results related to the distribution of the different PCDD/F congeners (Tetra, Penta, 395 Hexa, Hepta and Octa) in the MSWI residues, on geo-textiles samples, and in the 396 road soils, for all sites, are illustrated by the example of site A trench T2 (Figure 3) 397 and site C (Figure 4).

398 For site $A$, regarding the MSWI residue $\left(A_{M 2 / 14-29} ; A_{M 2 / 35-45} ; A_{M 2 / 45-65} ; A_{M 2 / 65-85}\right)$ they 399 show the predominance of OctaCDD, and the secondary importance of HeptaCDD 400 and HeptaCDF. For site C, they show the predominance of OctaCDD and OctaCDF 401 in the MSWI residue and the secondary importance of HeptaCDD. The geo-textile of 402 site $\mathrm{C}$ also show the predominance of OctaCDD and the secondary importance of 403 HeptaCDD.

404 For MSWI residues, the distribution between dioxin and furan congeners is provided 405 in Table 2. The proportion of dioxin congeners is of $50 \%$ for $\mathrm{C}_{\mathrm{M} 1}$ but it is higher for 406 other samples: $73 \%$ for $B_{M 1} ; 74$ to $79 \%$ for $D_{M}$ and 57 to $97 \%$ for $A_{M}$.

407 The distribution between dioxin and furan congeners is provided in Table 4 for geo408 textiles. In the geo-textile from site $\mathrm{D}$, the proportion of dioxin congeners $(74-75 \%)$ is 
equivalent to that of the above MSWI residue. For site C, it is higher (69\%) to that of

410 the MSWI residue.

411 The distribution between dioxin and furan congeners is provided in Table 5 for road

412 soils. For road soils, the proportion of dioxin congeners for all sites, ranges from 54 to

$41389 \%$. For sites A, B and D it is comparable to the distribution observed for the MSWI

414 residue. For site $\mathrm{C}$, it is higher.

415 The distribution between dioxin and furan congeners is provided in Table 6 for

416 reference soils. It is comparable to that of the respective road soils, $85 \%$ for $\mathrm{B}_{\mathrm{R}} ; 72 \%$

417 for $C_{R} ; 69$ to 90 for $A_{R}$.

418 The toxicity of PCDD/F varies substantially depending on the different congeners. It

419 is generally agreed that only 17 out of the 210 dioxin and furans congeners are toxic.

420 The examination of is 2,3,7,8-TetraCDD content in the different samples of MSWI

421 residue samples, geo-textiles, road soils and reference soils, reveals that its amount

422 in road soils is very low.

423 For road soils (Table 5), contents range from less than 0.04 ng. $\mathrm{kg}^{-1}$ (samples $\mathrm{A}_{\mathrm{S} 2 / 85-90}$ 424 and $D_{S 2 / 35-45}$ ) to $2.35 \mathrm{ng} \cdot \mathrm{kg}^{-1}$ (sample $A_{S 1 / 42-52}$ ), not very different from those of 425 reference soils (Table 6), ranging from less than $0.01 \mathrm{ng}^{\mathrm{kg}}{ }^{-1}$ (samples $\mathrm{B}_{\mathrm{R} / 0-20}$ and $426 \mathrm{C}_{\mathrm{R} / 0-5}$ ) to less than $0.9 \mathrm{ng} \cdot \mathrm{kg}^{-1}$ (sample $\mathrm{A}_{\mathrm{R} / 0-20}$ ).

427 As a matter of comparison, for MSWI residues (Table 2), the 2,3,7,8-TetraCDD 428 content is below $1.5 \mathrm{ng} \cdot \mathrm{kg}^{-1}$ for site $\mathrm{A}$, and $\leq 50 \mathrm{ng} \cdot \mathrm{kg}^{-1}$ for sites $\mathrm{B}, \mathrm{C}$ and samples $429 D_{M 1}$ and $D_{M 3}$. Sample $D_{M 2}$ content is 190 ng. $\mathrm{kg}^{-1}$. For geo-textiles (Table 4), contents 430 are from 6.8 to $57.5 \mathrm{ng} \cdot \mathrm{kg}^{-1}$.

\section{Discussion}

\section{$432 \quad 6.1$ Characterization of MSWI residues}




\subsubsection{PCDD/F contents}

434 A great heterogeneity of MSWI residue PCDD/F contents, i.e. a factor 154 from 14.0 $435\left(A_{M 1}\right)$ to $2160 \mathrm{ng}$ I-TEQ.kg ${ }^{-1} \mathrm{DM}\left(D_{M 2}\right)$ is observed between sites. $A$ great 436 heterogeneity can also be observed in a site such as A (a factor 16 between 14.0 437 and 227 ng I-TEQ. $\left.\mathrm{kg}^{-1} \mathrm{DM}\right)$.

438 The lowest recorded value (14.0 ng I-TEQ.kg ${ }^{-1} \mathrm{DM}$ for $\mathrm{A}_{\mathrm{M1-12-24}}$ ) is in the middle of the 439 range of values reported by Damien (1997) for bottom ash produced by recent 440 incinerators in France in the 1990's (4.0 to 20.6 ng l-TEQ. kg ${ }^{-1}$ DM). All other contents 441 are two times to 100 times above the maximum value recorded by Damien Such 442 results are also well above the contents reported by Badreddine and Drouadaine 443 (2006) on MSWI bottom ash from recent incineration and treatment facilities (i.e. 444 around $10 \mathrm{ng}$ I-TEQ. $\mathrm{kg}^{-1} \mathrm{DM}$ ) (Figure 5). Highest values $\left(\mathrm{M}_{\mathrm{D}}\right)$ are even above the

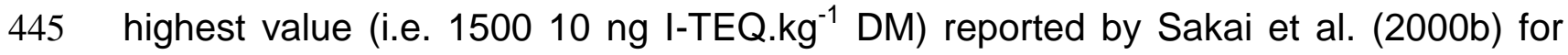
446 Japan. A comparison showing difference between MSWI residue from the old and 447 from recent site was proposed in figure 5.

\subsubsection{Importance of the fine fraction}

449 The analyses of size distribution of MSWI residues have shown an important 450 proportion of the fine fraction.

451 The possible relation between the particle size and the PCDD/F content was 452 postulated in an earlier study (Badreddine et al., 2003). The good relation between 453 the PCDD/F content and the particle size demonstrates that the fine fraction is 454 enriched with PCDD/F compounds. The sub-sample with the finest fraction $(<0.1$ $455 \mathrm{~mm}$ ) shows by far a higher PCDD/F content (6590 ng I-TEQ.kg ${ }^{-1}$ ), 7 times above the 456 other particle fractions. As the fraction below $0.1 \mathrm{~mm}$ represents less than $10 \%$ of the 
457 all graded aggregate (MSWI residue), this means that at least 659 ng I-TEQ.kg ${ }^{-1}$ (i.e.

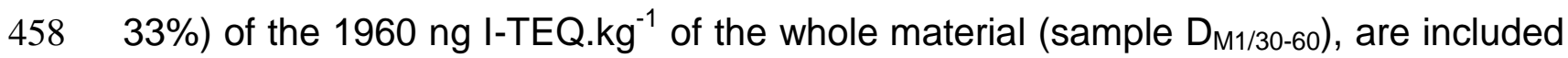
459 in the finest fraction.

460 These results confirm the assumption of the relation between the high value of the $461 \mathrm{PCDD} / \mathrm{F}$ and the presence of fly ash mixed with bottom ash before 1991 in France. 462 Indeed, the PCDD/F levels in fly ash are generally much higher than in bottom ash 463 (Mac Kay, 2002). Chang and Chung (1998) reported values between $41 \mathrm{ng} \cdot \mathrm{g}^{-1}$ and $464703 \mathrm{ng} \cdot \mathrm{g}^{-1}$ DM for MSWI fly ash).

465 Considering on one hand the range figures provided by Damien (1997) for MSWI 466 bottom ash (39 to $648 \mathrm{ng}$ I-TEQ. $\mathrm{kg}^{-1}$ ) and for MSWI fly ash (765 to $4815 \mathrm{ng} \mathrm{I-TEQ.kg}$ $\left.467{ }^{1}\right)$, and on the other hand the ratio of production between bottom ash $\left(250 \mathrm{~kg}^{-\mathrm{ton}^{-1}}\right)$ 468 and fly ash $\left(20 \mathrm{~kg} \cdot \mathrm{ton}^{-1}\right)$ from incineration, one reaches the range of 67 to $814 \mathrm{ng} \mathrm{I-}$ 469 TEQ. $\mathrm{kg}^{-1}$ for a theoretical mixture of bottom and fly ash. PCDD/F contents observed 470 for MSWI residues from site $A$ trench $T 2\left(A_{M 2}\right)$, from site $B\left(B_{M 1}\right)$ and site $C\left(C_{M 1}\right)$ are 471 in this range. The sample from site $A$ trench $T 1$ is below, but those from site $D$ are 472 two times above the highest value of the theoretical range.

\section{$473 \quad$ 6.1.3 Mobility of PCDD/F}

474 Very low PCDD/F releases were assert (0.0219 and $0.0441 \mathrm{ng}$ I-TEQ.kg $\left.{ }^{-1}\right)$. 475 Compared to the total content of PCDD/F compounds in the respective MSWI

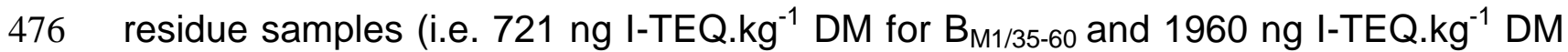
$477 D_{M 1 / 10-30}$ ), the released fractions are respectively 0.003 and $0.002 \%$ of the total 478 PCDD/F amount.

479 The low value recorded can be linked to the low solubility of the PCDD/F and the 480 presence of the $\mathrm{PCDD} / \mathrm{F}$ in the particles superior to $0.45 \mu \mathrm{m}$ (Badreddine et al., 
2003). Depending on congeners, solubility values are comprised between $0.7410^{-7}$ and $3.7510^{-3}$ for PCDD (Inserm, 2000) and between $4.1910^{-4}$ and $1.1610^{-6}$ for PCDF (OMS, 1997).

\subsection{Assessment of PCDD/Ffate}

\subsubsection{PCDD/F contents of road soil}

The heterogeneity among all road soil PCDD/F contents, i.e. a factor 9 between 0.74 $\left(A_{S 1}\right)$ and $7.23 \mathrm{ng}$ I-TEQ. $\mathrm{kg}^{-1} \mathrm{DM}\left(\mathrm{B}_{\mathrm{S1}}\right)$ is far lower than among MSWI residues. Such values are low in comparison to those reported by Nominé (1999) for soils of urban areas in the absence of neighbouring sources of pollution (from $<1$ to more than 30 ng. $\mathrm{kg}^{-1}$ I-TEQ. $\mathrm{kg}^{-1} \mathrm{DM}$ ), for soils nearby MSW incineration plants (more than 1000 ng. $\mathrm{kg}^{-1}$ I-TEQ. $\mathrm{kg}^{-1} \mathrm{DM}$ ), and even to those of soils of pasture in Europe (from $<1$ to 43 ng.kg-1 I-TEQ.kg-1 DM).

\subsubsection{Comparison to reference soils' contents}

In order to assess the state of road soils, comparison can be made with their respective reference soils. Depending on the context (more or less potential sources of pollution in the area), the difference between them is negative (site B), negligible (site A), or even positive (site $\mathrm{C}$ where pollution sources affect the reference soil).

Indeed, regarding Site B, the ratio between the average contents in road soil (3.9 ng I-TEQ. kg ${ }^{-1}$ DM) and the reference soil (0.92 ng I-TEQ. $\left.\mathrm{kg}^{-1} \mathrm{DM}\right)$ is around 4.

Regarding Site $A$, depending on the consideration of sample $A_{R / 0-20}$ or not in the comparison, one can consider that the PCDD/F content in the road soil is lower (9 times) or slightly higher (1.04 ng I-TEQ. $\mathrm{kg}^{-1} \mathrm{DM}$ in average for road soil vs $0.44 \mathrm{ng} \mathrm{I-}$ TEQ.kg ${ }^{-1}$ DM in average for reference soil) in trench T1. Considering trench T2, the 
504 conclusion is the same, i.e. respectively 4 times lower, or slightly higher $(2.17 \mathrm{ng} \mathrm{I-}$

505 TEQ.kg-1 DM in average for road soil vs 0.44 ng I-TEQ. $\mathrm{kg}^{-1} \mathrm{DM}$ ).

506 In the case of Site $\mathrm{C}$, the content in the road soil sample $\left(\mathrm{C}_{\mathrm{S} 1 / 88-93}\right)$ is 2 times lower

507 than in the reference soil (5.94 $\mathrm{ng}$ I-TEQ. $\mathrm{kg}^{-1} \mathrm{DM}$ in average). Located in a large

508 urban area, references soil of Site $\mathrm{C}$ can have been affected for years by several

509 sources, which can lead to a situation similar as for Site A.

$510 \quad$ 6.2.3 Comparison to MSWI residues' contents

511 Some vertical profiles of PCDD/F contents in road soils (sites A and B) show 512 decreasing values from the upper sample, downward, indication of a possible contact

513 effect of the MSWI residue layer. Contents in the road soil are however low and the

514 transition with the MSWI residue layer with high contents, is very well marked.

515 For sites $A$ and $B$, where the influence of the geo-textile is not susceptible to

516 interfere, the ratio between the road soil upper sample content and the MSWI residue

517 layer content can serve as an indicator. Regarding Site A trench T1, this ratio (1.35 518 vs 14.0 ng I-TEQ.kg ${ }^{-1}$ DM) is 9.6\%, and for trench T2 (2.98 vs 101 ng I-TEQ.kg ${ }^{-1}$ DM

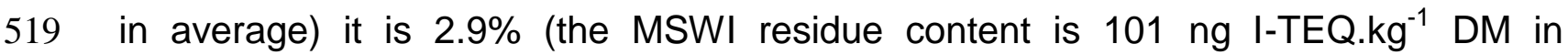

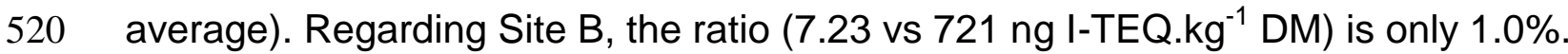

521 For sites with geo-textiles, such ratios are $1.2 \%$ for site C (2.87 vs $235 \mathrm{ng} \mathrm{l-TEQ. \textrm {kg } ^ { - 1 }}$

522 DM), or lower for site D, i.e. $0.04 \%$ for trench T1 (0.86 vs 1960 ng I-TEQ.kg ${ }^{-1}$ DM)

523 and $0.1 \%$ for trench T2 (2.22 vs 2160 ng I-TEQ. $\mathrm{kg}^{-1} \mathrm{DM}$ ).

524 6.3. Role of geo-textiles

525 The PCDD/F load of geo-textiles compared to the content of the MSWI residue

526 located just above is equal to $74 \%$ of the latter in the case of site $\mathrm{C}\left(\mathrm{C}_{\mathrm{G} 1} / \mathrm{C}_{\mathrm{M} 1}\right)$. For 
527 site $\mathrm{D}$, such ratios are equal to $86 \%$ in the case of trench $\mathrm{T} 1\left(\mathrm{D}_{\mathrm{G} 1} / \mathrm{D}_{\mathrm{M} 1}\right)$ but only $35 \%$

528 in the case of trench $\mathrm{T} 2\left(\mathrm{D}_{\mathrm{G} 2} / \mathrm{D}_{\mathrm{M} 2}\right)$.

529 In order to assess the role of geo-textiles toward the possible PCDD/F transfer, their 530 load can also be compared to the content of the road soil upper sample. In the case 531 of site $\mathrm{C}$, Such ratio is $61\left(\mathrm{C}_{\mathrm{G} 1} / \mathrm{C}_{\left.\mathrm{S}_{1}\right)}\right)$, and it is higher in the case of site $\mathrm{D}, 1860$ for 532 trench $\mathrm{T} 1\left(\mathrm{D}_{\mathrm{G} 1} / \mathrm{D}_{\mathrm{S} 1}\right)$, and 339 for trench $\mathrm{T} 2\left(\mathrm{D}_{\mathrm{G} 2} / \mathrm{D}_{\mathrm{S} 2}\right)$.

533 The role of the geo-textile inserted between the MSWI residue layer and the road soil 534 should be clarified : may be it acts as a filter toward the transfer of fine particles 535 downward. But may be the porosity of the road soil in itself is low enough to act as a 536 filter, which would explain the slightly higher PCDD/F contents in some road soil 537 upper samples.

\section{Conclusion}

539 This study shows that some MSWI residues used for road construction before the 540 enforcement of the 1991 order can contain very high amount of PCDD/F compared to 541 the MSWI bottom ash produced and used afterward. The heterogeneity between 542 MSWI residues can be great from one road site to another but also on a single site.

543 The important contribution of the fraction below $0.1 \mathrm{~mm}$ to the MSWI residue total 544 contents of PCDD/F was asserted. Crossed with leaching test results, this indicates 545 that the fraction between 0.45 and $100 \mu \mathrm{m}$ should be investigated in more detail in 546 order to specify the most loaded particle sizes.

547 As a whole, road soils PCDD/F contents are below the contents recorded for ordinary 548 urban or rural soils, and consequently, no significant difference is observed with local 
549 reference soils. This indicate the absence of transfer of MSWI residue to the road 550 soil.

551 In addition, thanks to the very low proportion of the 2,3,7,8-TetraCDD congener, the 552 noxiousness of road soils is reduced. In the presence of geo-textile or not, the $553 \mathrm{PCDD} / \mathrm{F}$ content reduction between the MSWI residue and the road soil is great. The 554 role of the geo-textile inserted between the MSWI residue layer and the road soil 555 should be clarified.

556 Considering the improvements brought by the enforcement of the 1991 order 557 regarding the fate of MSWI fly ash and those brought by the more recent air pollution 558 control systems, the diagnosis achieved thanks to this study provides a rather 559 positive and reassuring insight concerning the effect of today produced and used 560 MSWI bottom ash in road construction.

\section{References}

562 - Adam, P., Dony, Y., Vincot, Y., 1996. Valorisation des mâchefers d'incinération en 563 technique routière : Evaluation de leur comportement en condition réelle d'utilisation, 564 Déchets Sciences et Techniques 4, 11-14.

565 - AGHTM, 1994. Politique de gestion des déchets en France: Etat de l'art de 566 l'incinération. Techniques Sciences et Méthodes 9, 475-510.

567 - Association Française de Normalisation (AFNOR), 1994. NF ISO 11465 standard, 568 Soil quality - Determination of dry matter and water content on a mass basis 569 Gravimetric method.

570 - Association Française de Normalisation (AFNOR), 1992. NF X 31-210 standard, 571 Waste - Leaching of waste. 
572 - Association Française de Normalisation (AFNOR), 2002. NF EN 12457-2 standard.

573 Characterization of waste - Leaching - Compliance test for leaching of granular 574 waste materials and sludges - Part 2: one stage batch test at a liquid to solid ratio of $57510 \mathrm{l} / \mathrm{kg}$ for materials with particle size below $4 \mathrm{~mm}$.

576 - Autret, E., Berthier F., Luszezanec, A., Nicolas, F., 2007. Incineration of municipal 577 and assimilated wastes in France: Assessment of latest energy and material 578 recovery performances, Journal of Hazardous Materials, B139, 569-574.

579 - Badreddine, R., Bartet, B., François, D,. Pepin, G., 2003. Impact sur les sols des 580 dioxines de MIOM utilisés en technique routière. Déchets Sciences et Techniques $58129,16-21$.

582 - Badreddine, R., Drouadaine, I., 2006. Evaluation du transfert des composés 583 organiques des MIOM utilisés en sous-couche routière dans des ouvrages de 584 construction récente. Déchets Sciences et Techniques 43, 21-26.

585 - Bartet, B., Pépin, G., Nominé, M., 2001. Dioxine dans les MIOM : Teneurs 586 observées et étude préliminaire de leur potentiel de transfert vers l'environnement. 587 In : BRGM and ADEME (Eds). Quel avenir pour les MIOM ?, BRGM, Orléans, 588 France, pp. 118-123.

589 - Chandler, A.J., Eighmy, T.T., Hartlén, J., Hjelmar, O., Kosson, D.S., Sawell, S.E., 590 van der Sloot, H.A., Vehlow, J., 1997, Municipal Solid Waste Incinerator Residues, 591 Studies in Environmental Science, vol. 67. Elsevier, Amsterdam, The Netherlands.

592 - Chang, M.-B, Chung, Y.-T., 1998. Dioxin contents in fly ashes of MSW Incineration. 593 Chemosphere 36-9, 1959-1968. 
594 - Damien, A., 1997. Etude des caractéristiques intrinsèques de certains déchets des 595 usines d'incinération d'ordures ménagères et de déchets industriels spéciaux. 596 Ministère de l'Environnement and TIRU, Paris.

597 - Drouadaine, I., Seignerie C., Jozon C., 1997. Etude de l'impact environnemental de 598 la valorisation des mâchefers d'incinération en technique routière, Techniques 599 Sciences et Méthodes 10, 48-54.

600 - Drouadaine, I., Badreddine, R., 2003. Valorisation des MIOM en technique routière: 601 Evaluation de leur impact sur l'environnement par la réalisation d'une chaussée 602 expérimentale. Déchets Sciences et Techniques, № spécial "Les MIOM (Mâchefers 603 d'Incinération d'Ordures Ménagères)", $4^{\mathrm{e}}$ trimestre 2003, 32-38.

604 - François, D., Auzizeau, J., Raimbault, G., 2003. Hydrodynamic characterization of 605 municipal solid waste incinerator bottom ashes used in road construction, Revue 606 Française de Géotechnique 103, 25-32.

607 - French ministry for Environment, 1991. Departmental order related to urban waste 608 incineration facilities. Paris.

609 - French ministry for Environment, 1994. Memorandum related to the disposal of 610 urban waste incineration bottom ash. Paris.

611 - French ministry for Public Works and Transports (MELT), 1997. French design 612 manual for pavement structures. SETRA and LCPC, Paris.

613 - Jullien, A., François, D., 2006. Soil indicators used in road environmental impact 614 assessments, Resour. Conserv. Recy. 48, 101-124.

615 - Mac Kay, G., 2002. Dioxin characterisation, formation and minimisation during 616 municipal solid waste (MSW) incineration: review. Chem. Eng. J. 86 343-368. 
617 - Nominé, M., 1999. Méthodologie pour l'évaluation de la contamination par les

618 dioxines au voisinage d'une source fixe. Study report. INERIS, Verneuil-en-Halatte.

619 - Paris, I., Hubscher V., Leroy M.J.F., 1997. Etude du comportement de mâchefers

620 de DIS utilisés en technique routière - Comparaison avec des mâchefers d'OM.

621 Techniques Sciences et Méthodes 4, 27-34.

622 - Sakai, S., Urano, S., Takatsuki, H., 2000a. Leaching behaviour of PCBs and 623 PCDDs/Dfs from waste materials, Waste Management 20, 241-247.

624 - Sakai, S., Mizutani, S., Uchida, T., Yoshida, T., 2000b. Substance flow analysis of 625 persistent toxic substances in the recycling process of municipal solid waste 626 incineration residues, Waste Management Series, vol. 1, Waste Materials in 627 Construction Wascon 2000 - Proceedings of the International Conference on the 628 Science and Engineering of Recycling for Environmental Protection, Harrogate, 629 England, pp. 893-903.

630 - Service d'Etudes Techniques des Routes et Autoroutes (SETRA) and Laboratoire 631 Central des Ponts et Chaussées (LCPC), 2000. Réalisation des remblais et des 632 couches de formes (Construction of embankments and capping layers), SETRA, 633 Paris, France.

634 - Silvestre P., Rampignon, J.P., 1995. Valorisation en structure routière du mâchefer 635 d'incinération d'ordures ménagères de l'usine de Lyon-Sud, Techniques Sciences et 636 Méthodes 5, 427-430.

637 - Stanmore, B.R., 2004. The formation of dioxins in combustion systems. Combust. 638 Flame 136. 398-427. 
639 - van Ganse, R., 1978. Les infiltrations dans les chaussées: évaluations

640 prévisionelles. In Proceedings of the International Symposium on Road Drainage.

641 Federal Office of Highways and Rivers, Bern, Switzerland, pp. 176-192.

642

643 List of Figures:

644 Figure 1a: The typical road structure in France

645 Figure 1b: Road structures of both sites

646 Figure 2: Relation between particle size and PCDD/F content

647 Figure 3: PCDD/F congeners distribution in materials from site A (trench T2)

648 Figure 4: PCDD/F congeners distribution in materials from site $\mathrm{C}$

649 Figure $5: \mathrm{PCDD} / \mathrm{F}$ content variation with age of MSWI residue production

650

651 List of Tables

652 Table 1 : Overview of the set of samples

653 Table $2:$ PCDD/F contents of MSWI residues

654 Table $3:$ PCDD/F contents from eluates

655 Table $4:$ PCDD/F loads of geo-textiles

656 Table $5:$ PCDD/F contents of road soils

657 Table $6:$ PCDD/F contents of reference soils

658 
659

660

661

662

663

664

665

666

667

668

669

670

671

672

673

674

681

682

683

684

685

686

687

688

689

690

691

692

693

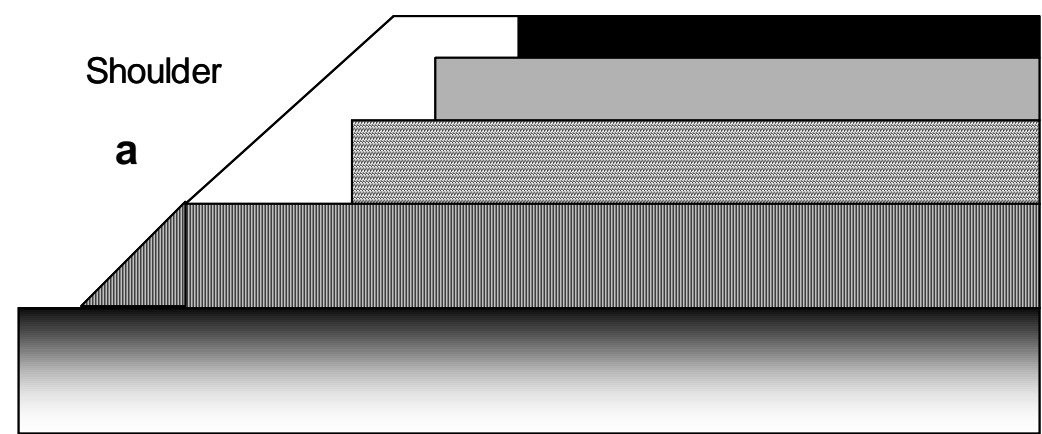

Surface course

Base

Sub-base

Capping layer

Subgrade

\begin{tabular}{|c|c|c|c|c|c|}
\hline & Site & A & B & C & $\mathrm{D}$ \\
\hline & $\begin{array}{l}\text { Surface } \\
\text { course }\end{array}$ & $\begin{array}{l}4 \mathrm{~cm} \text { bituminous } \\
\text { concrete }\end{array}$ & $\begin{array}{c}4 \mathrm{~cm} \text { bituminous } \\
\text { concrete }\end{array}$ & $\begin{array}{c}4 \mathrm{~cm} \text { bituminous } \\
\text { concrete }\end{array}$ & $\begin{array}{l}4 \mathrm{~cm} \text { bituminous } \\
\text { concrete }\end{array}$ \\
\hline 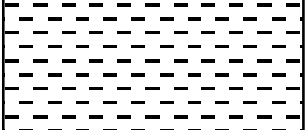 & Base & $10 \mathrm{~cm}$ & $22 \mathrm{~cm}$ & $42 \mathrm{~cm}$ & $\begin{array}{l}30 \mathrm{~cm} \text { MSWI } \\
\text { residue above } \\
\text { geo-textile }\end{array}$ \\
\hline (2) & Sub-base & $\begin{array}{l}70 \mathrm{~cm} \text { MWSI } \\
\text { residue }\end{array}$ & $\begin{array}{l}25 \mathrm{~cm} \text { MWSI } \\
\text { residue }\end{array}$ & $\begin{array}{l}40 \mathrm{~cm} \text { MSWI } \\
\text { residue above } \\
\text { geo-textile }\end{array}$ & - \\
\hline d & Road soil & Sand & Silt-clay & Silt & Silt \\
\hline
\end{tabular}

Figure 1: (a) : The typical road structure in France (MELT, 1997)

(b) : roads structures of both sites 
Figure 2 : relation between particle size and PCDD/F content
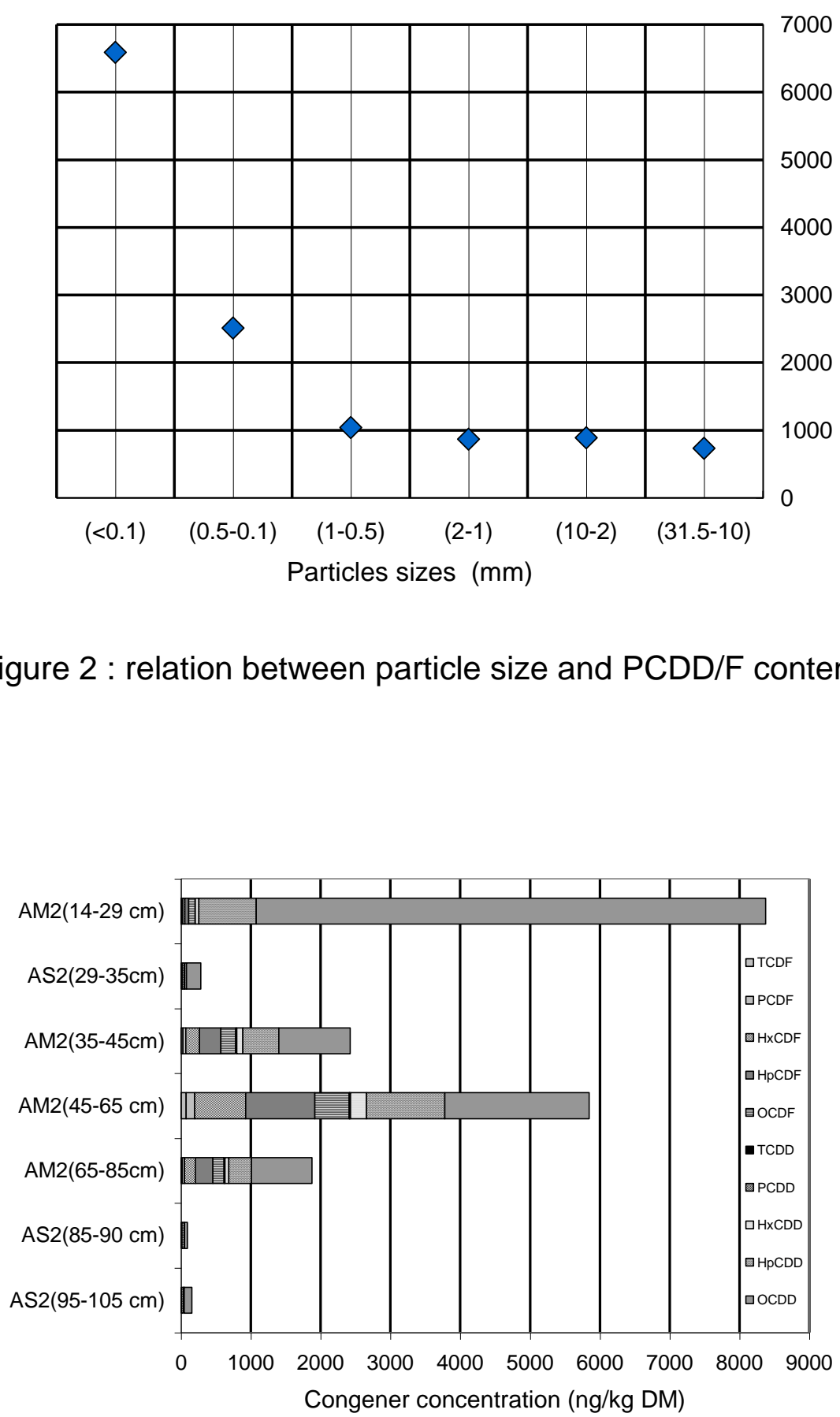

Figure 3 : PCDD/F congeners distribution in materials from site A (trench T2)

(1) 


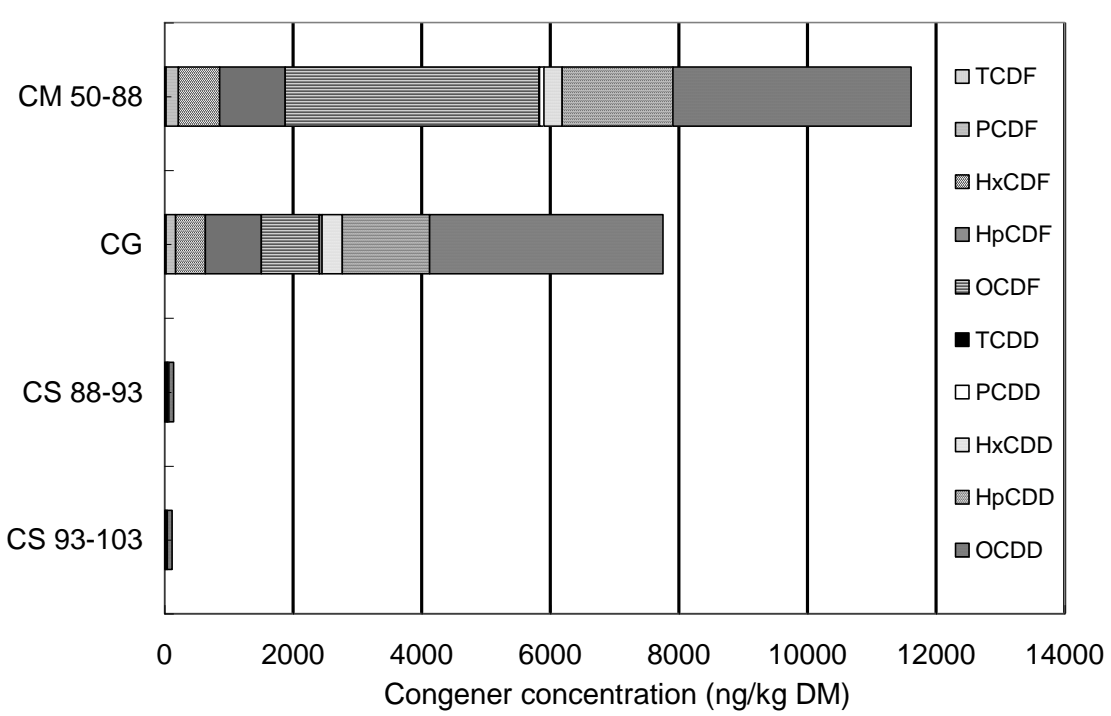

Figure 4 : PCDD/F congeners distribution in materials from site $\mathrm{C}$

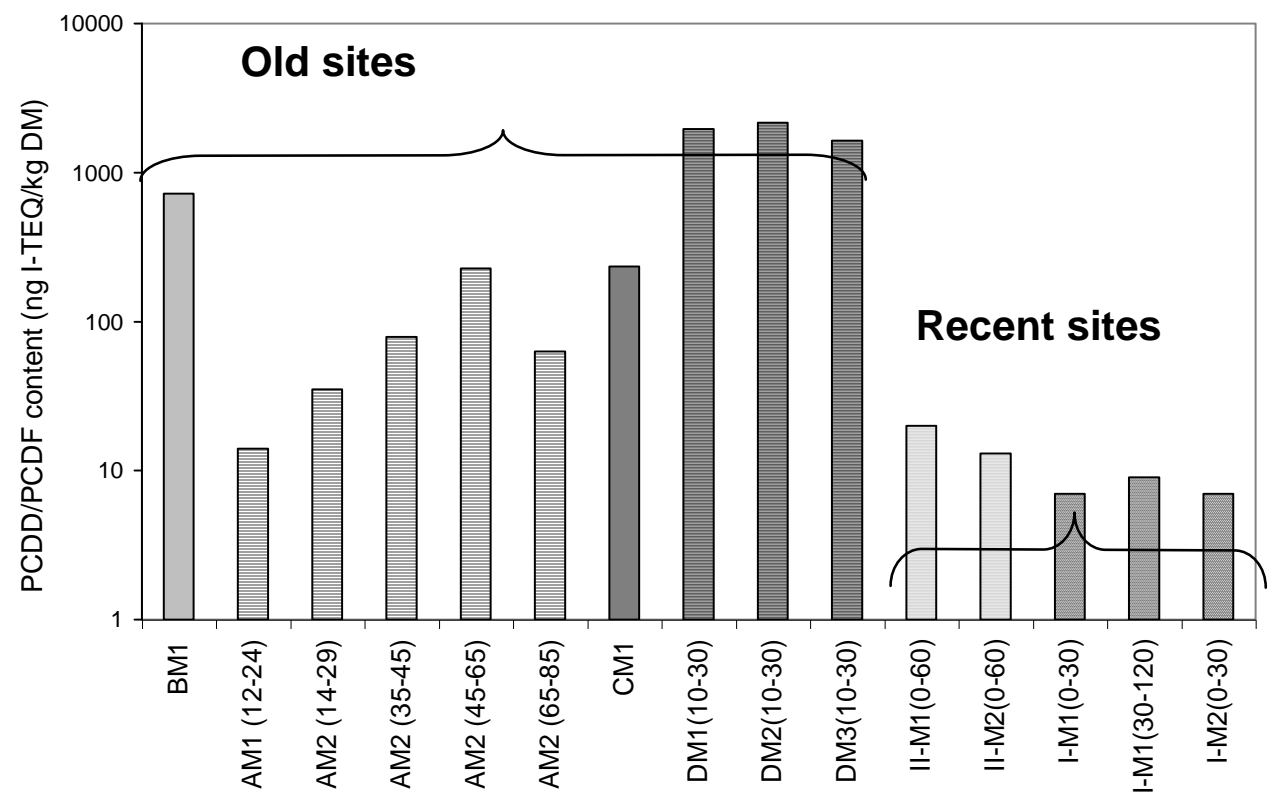


Table 1: Overview of the set of samples

\begin{tabular}{|l|c|c|c|c|}
\hline Site & A & B & C & D \\
\hline Material $(\mathrm{M})$ & $\mathrm{A}_{\mathrm{M} 1}, \mathrm{~A}_{\mathrm{M} 2}$ & $\mathrm{~B}_{\mathrm{M} 1}$ & $\mathrm{C}_{\mathrm{M} 1}$ & $\mathrm{D}_{\mathrm{M} 1}, \mathrm{D}_{\mathrm{M} 2}, \mathrm{D}_{\mathrm{M} 3}$ \\
\hline Geo-textile $(\mathrm{G})$ & - & - & $\mathrm{C}_{\mathrm{G} 1}$ & $\mathrm{D}_{\mathrm{G} 1}, \mathrm{D}_{\mathrm{G} 2}$ \\
\hline Road soil $(\mathrm{S})$ & $\mathrm{A}_{\mathrm{S} 1}, \mathrm{~A}_{\mathrm{S} 2}$ & $\mathrm{~B}_{\mathrm{S} 1}$ & $\mathrm{C}_{\mathrm{S} 1}$ & $\mathrm{D}_{\mathrm{S} 1}, \mathrm{D}_{\mathrm{S} 2}, \mathrm{D}_{\mathrm{S} 3}$ \\
\hline $\begin{array}{l}\text { Reference soil } \\
\text { (R) }\end{array}$ & $\mathrm{A}_{\mathrm{R}}$ & $\mathrm{B}_{\mathrm{R}}$ & $\mathrm{C}_{\mathrm{R}}$ & - \\
\hline
\end{tabular}

784

785

786

Table 2 : PCDD/F contents of MSWI residues

\begin{tabular}{|c|c|c|c|c|c|}
\hline Site & \multicolumn{5}{|c|}{$\mathbf{A}$} \\
\hline Sample & $\mathrm{A}_{\mathrm{M} 1 / 12-24}$ & $\mathrm{~A}_{\mathrm{M} 2 / 14-19}$ & $\mathrm{~A}_{\mathrm{M} 2 / 35-45}$ & $\mathrm{~A}_{\mathrm{M} 2 / 45-65}$ & $\mathrm{~A}_{\mathrm{M} 2 / 65-85}$ \\
\hline ITE (ng I-TEQ.kg $\left.{ }^{-1} \mathrm{DM}\right)$ & 14.0 & 35.7 & 78.7 & 227 & 63.2 \\
\hline $\begin{array}{l}\text { 2,3,7,8-TetraCDD } \\
\left(\text { ng. } \mathrm{kg}^{-1}\right)\end{array}$ & 0.79 & 1.46 & $<0.33$ & $<2.15$ & $<0.15$ \\
\hline $\begin{array}{l}7 \text { Dioxin congeners } \\
\left(\text { ng. } \mathrm{kg}^{-1}\right)\end{array}$ & 691 & 8176 & 1643 & 3436 & 1257 \\
\hline $\begin{array}{l}10 \text { Furan congeners } \\
\left(\mathrm{ng} \cdot \mathrm{kg}^{-1}\right)\end{array}$ & 94 & 211 & 830 & 2576 & 670 \\
\hline Dioxin $(\%)$ & 88 & 97 & 66 & 57 & 65 \\
\hline Site & B & $\mathbf{C}$ & & $\mathbf{D}$ & \\
\hline Sample & $\mathrm{B}_{\mathrm{M} 1 / 35-60}$ & $\mathrm{C}_{\mathrm{M} 1 / 50-88}$ & $\mathrm{D}_{\mathrm{M} 1 / 10-30}$ & $\mathrm{D}_{\mathrm{M} 2 / 10-30}$ & $\mathrm{D}_{\mathrm{M} 3 / 10-30}$ \\
\hline ITE (ng I-TEQ.kg $\left.{ }^{-1} \mathrm{DM}\right)$ & 721 & 235 & 1960 & 2160 & 1640 \\
\hline $\begin{array}{l}\text { 2,3,7,8-TetraCDD } \\
\left(\text { ng. } \mathrm{kg}^{-1}\right)\end{array}$ & 21.6 & 9.16 & 49.6 & 190 & 51.2 \\
\hline $\begin{array}{l}7 \text { Dioxin congeners } \\
\left(\text { ng. } \mathrm{kg}^{-1}\right)\end{array}$ & 25152 & 5864 & 95852 & 81009 & 91743 \\
\hline $\begin{array}{l}10 \text { Furan congeners } \\
\left(\mathrm{ng} \cdot \mathrm{kg}^{-1}\right)\end{array}$ & 9121 & 5825 & 31853 & 21904 & 31822 \\
\hline Dioxin $(\%)$ & 73 & 50 & 75 & 79 & 74 \\
\hline
\end{tabular}

Table 3 : PCDD/F contents from eluates

\begin{tabular}{|l|c|c|}
\hline Site & B & D \\
\hline Sample & $\mathrm{B}_{\mathrm{M} 1 / 35-60}$ & $\mathrm{D}_{\mathrm{M} 1 / 10-30}$ \\
\hline ITE $\left(\mathrm{pg} \mathrm{I-TEQ.1}{ }^{-1}\right)$ & 2.19 & 4.41 \\
\hline
\end{tabular}


Table 4 : PCDD/F loads of geo-textiles

\begin{tabular}{|l|c|c|c|}
\hline Site & C & \multicolumn{2}{|c|}{ D } \\
\hline Sample & $\mathrm{C}_{\mathrm{G} 1}$ & $\mathrm{D}_{\mathrm{G} 1}$ & $\mathrm{D}_{\mathrm{G} 2}$ \\
\hline ITE (ng I-TEQ.kg & & 754 \\
\hline $\begin{array}{l}2,3,7,8-\text { DetraCDD } \\
(\text { ng.kg }\end{array}$ & 175 & 1600 & 57.5 \\
\hline $\begin{array}{l}7 \text { Dioxin congeners } \\
(\text { ng.kg-1) }\end{array}$ & 6.84 & 34.9 & 28437 \\
\hline $\begin{array}{l}\text { 10 Furan congeners } \\
(\text { ng.kg-1) }\end{array}$ & 2407 & 74545 & 9317 \\
\hline Dioxin $(\%)$ & 69 & 26384 & 75 \\
\hline
\end{tabular}

Table 5 : PCDD/F contents of road soils

\begin{tabular}{|c|c|c|c|c|c|c|c|c|c|}
\hline \multirow[b]{2}{*}{ Sample } & \multicolumn{7}{|c|}{$\mathbf{A}$} & \multicolumn{2}{|r|}{ B } \\
\hline & $\begin{array}{c}\mathrm{A}_{\mathrm{S} 1 / 32-} \\
37\end{array}$ & $\mathrm{~A}_{\mathrm{S} 1 / 37-}$ & $\begin{array}{c}\mathrm{A}_{\mathrm{S} 1 / 42-} \\
52\end{array}$ & \multicolumn{2}{|c|}{$\begin{array}{c}\mathrm{A}_{\mathrm{S} 2 / 29-} \\
35\end{array}$} & $\begin{array}{c}\mathrm{A}_{\mathrm{S} 2 / 85-} \\
90\end{array}$ & \begin{tabular}{c|c}
$85-$ & $\mathrm{A}_{\mathrm{S} 2 / 95}$ \\
105
\end{tabular} & \begin{tabular}{c|c}
$5-$ & $\mathrm{B}_{\mathrm{S} 1 / 60-}$ \\
70
\end{tabular} & $\begin{array}{c}\mathrm{B}_{\mathrm{S} 1 / 70-} \\
\quad 80\end{array}$ \\
\hline ITE (ng I-TEQ.kg $\left.{ }^{-1} \mathrm{DM}\right)$ & 1.35 & 0.74 & 24.8 & \multicolumn{2}{|c|}{2.98} & 2.24 & 1.31 & 7.23 & 0.57 \\
\hline $\begin{array}{l}\text { 2,3,7,8-TetraCDD } \\
\left(\text { ng. } \mathrm{kg}^{-1}\right)\end{array}$ & 0.11 & 0.1 & 2.53 & \multicolumn{2}{|c|}{0.24} & $<0.04$ & $04<0.32$ & 0.46 & $<0.07$ \\
\hline $\begin{array}{l}7 \text { Dioxin congeners } \\
\left(\text { ng. } \mathrm{kg}^{-1}\right)\end{array}$ & 46.2 & 63.2 & 410.8 & \multicolumn{2}{|c|}{238.3} & 44.5 & 115.6 & 280.7 & 52.3 \\
\hline $\begin{array}{l}10 \text { Furan congeners } \\
\left(\text { ng. } \mathrm{kg}^{-1}\right)\end{array}$ & 10.9 & 7.8 & 354.3 & \multicolumn{2}{|c|}{45.1} & 28.9 & 20.0 & 111.2 & 11.2 \\
\hline Dioxin $(\%)$ & 81 & 89 & 54 & \multicolumn{2}{|c|}{84} & \multicolumn{2}{|c|}{61} & 72 & 82 \\
\hline Site & $\mathbf{C}$ & \multicolumn{8}{|c|}{$\mathbf{D}$} \\
\hline Sample & $\mathrm{C}_{\mathrm{S} 1 / 88-93}$ & $\mathrm{D}_{\mathrm{S} 1 / 30-35}$ & \multicolumn{2}{|c|}{${ }_{5} \mathrm{D}_{\mathrm{S} 1 / 35-45}$} & & & $\mathrm{D}_{\mathrm{S} 2 / 30-35}$ & $\mathrm{D}_{\mathrm{S} 2 / 35-45}$ & $\mathrm{D}_{\mathrm{S} 3 / 30-35}$ \\
\hline ITE (ng I-TEQ.kg ${ }^{-1}$ DM) & 2.87 & 0.86 & \multicolumn{2}{|c|}{0.79} & 1.9 & & 2.22 & 0.64 & 2.04 \\
\hline $\begin{array}{l}\text { 2,3,7,8-TetraCDD } \\
\left(\text { ng. } \mathrm{kg}^{-1}\right)\end{array}$ & $<0.10$ & $<0.05$ & \multicolumn{2}{|c|}{$<0.05$} & $<0$ & .11 & 0.21 & $<0.04$ & 0.19 \\
\hline $\begin{array}{l}7 \text { Dioxin congeners } \\
\left(\text { ng. } \mathrm{kg}^{-1}\right)\end{array}$ & 99.1 & 52.2 & \multicolumn{2}{|c|}{18.1} & 90 & & 70.4 & 12.4 & 95.9 \\
\hline $\begin{array}{l}10 \text { Furan congeners } \\
\left(\text { ng. } \mathrm{kg}^{-1}\right)\end{array}$ & 43.3 & 7.9 & \multicolumn{2}{|c|}{9.5} & 24 & & 22.7 & 4.6 & 28.8 \\
\hline Dioxin $(\%)$ & 70 & 87 & \multicolumn{2}{|c|}{66} & \multicolumn{2}{|c|}{79} & 76 & 73 & 77 \\
\hline
\end{tabular}


802 Table 6: PCDD/F contents of reference soils

\begin{tabular}{|c|c|c|c|c|c|c|c|c|}
\hline Site & \multicolumn{4}{|c|}{$\mathbf{A}$} & \multicolumn{2}{|c|}{ B } & \multicolumn{2}{|c|}{$\mathbf{C}$} \\
\hline Sample & $\mathrm{A}_{\mathrm{R} / 0-20}$ & $\begin{array}{c}\mathrm{A}_{\mathrm{R} / 20-} \\
\quad 40\end{array}$ & $\begin{array}{c}\mathrm{A}_{\mathrm{R} / 40-} \\
60\end{array}$ & $\begin{array}{c}\mathrm{A}_{\mathrm{R} / 80-} \\
95\end{array}$ & $\mathrm{~B}_{\mathrm{R} / 0-20}$ & $\mathrm{~B}_{\mathrm{R} / 60-80}$ & $\mathrm{C}_{\mathrm{R} / 0-5}$ & $\mathrm{C}_{\mathrm{R} / 5-15}$ \\
\hline ITE (ng I-TEQ. $\left.\mathrm{kg}^{-1} \mathrm{DM}\right)$ & 9.4 & 0.67 & 0.36 & 0.30 & 1.05 & 0.79 & 5.40 & 6.49 \\
\hline $\begin{array}{l}\text { 2,3,7,8-TetraCDD } \\
\left(\text { ng. } \mathrm{kg}^{-1}\right)\end{array}$ & $<0.9$ & 0.05 & $<0.02$ & $<0.03$ & $<0.01$ & $<0.19$ & $<0.01$ & $<0.18$ \\
\hline $\begin{array}{l}7 \text { Dioxin congeners } \\
\left(\text { ng.kg }{ }^{-1}\right)\end{array}$ & 216.8 & 58.5 & 41.9 & 50.0 & 109.3 & 35.2 & 240.0 & 200.0 \\
\hline $\begin{array}{l}10 \text { Furan congeners } \\
\left(\text { ng.kg }{ }^{-1}\right)\end{array}$ & 98.7 & 7.3 & 7.1 & 5.8 & 17.5 & 6.6 & 82.3 & 86.0 \\
\hline Dioxin $(\%)$ & 69 & 89 & 86 & 90 & 86 & 84 & 74 & 70 \\
\hline
\end{tabular}

803 